JKEP

Vol 6, No 1 (2021)

ISSN: 2338-9095 (Print)

ISSN: 2338-9109 (online)

\title{
Aplikasi Recovery Tidal Model dalam Pemberian Relaxation Therapy Pada Resiko Perilaku Kekerasan
}

\author{
Raphita Diorarta, Herni Susanti \\ Fakultas Ilmu Keperawatan Universitas Indonesia \\ Email: raphita.diorarta@ui.ac.id
}

\section{Artikel history}

Dikirim, April $08^{\text {th }}, 2021$

Ditinjau, May $25^{\text {th }}, 2021$

Diterima, May $27^{\text {th }}, 2021$

\begin{abstract}
Emotional problems are a symptom of violent behavior. Interaction of nerve activity between the hypothalamus, limbic structures (amygdala and hyppocampus), and the higher cortical centers which are psychophysiological events of emotion in the human system. The purpose of this case study is to see the application of Tidal Model recovery in mental health in the provision of relaxation therapy. The search method used is a case study, and literature review. The author selects the analyzed journals to find the effectiveness of relaxation therapy against the risk of violent behavior and a journal on recovery that links therapeutic communication between nurses and patients. In the discussion of this paper, the sub-theme of therapeutic relationship between nurses and patients is found and also the self-awareness of patients who are part of the Tidal Model. By implementing relaxation therapy with the Tidal Model approach, there is a reduction in signs and symptoms in patients. Recommendations for nurses are able to become more empathetic nurses in implementing therapy and can support and encourage patient awareness in carrying out therapies that will bring patients into recovery.
\end{abstract}

Keyword: relaxation therapy; recovery Tidal Model; the risk of violent behaviour

\begin{abstract}
ABSTRAK
Masalah emosi merupakan salah satu tanda gejala yang dimiliki oleh perilaku kekerasan. Interaksi aktivitas saraf antara hipotalamus, struktur limbik (amygdala dan hyppocampus), dan pusat - pusat korteks yang lebih tinggi yang merupakan psikofisiologis terjadinya emosi pada sistem manusia. Tujuan dari studi kasus ini adalah untuk melihat penerapan Tidal Model recovery in mental health pada pemberian relaxation therapy. Metode telusur yang digunakan adalah studi kasus, dan literature review. Penulis memilih jurnal yang sudah dianalisa didapatkan keefektifan relaxation therapy terhadap resiko perilaku kekerasan dan jurnal mengenai pemulihan yang mengaitkan komunikasi terapetik antara perawat dan pasien. Pada pembahasan penulisan ini didapatkan sub tema therapeutic relationship antara perawat dan pasien dan juga self awareness dari pasien yang merupakan bagian dari Tidal Model. Dengan pelaksanaan relaxation therapy dengan pendekatan Model Tidal adanya pengurangan tanda dan gejala pada pasien. Rekomendasi untuk perawat mampu untuk menjadi perawat yang lebih
\end{abstract}


empati dalam menerapkan terapi dan dapat mendukung dan mendorong kesadaran pasien dalam melaksanakan terapi yang akan membawa pasien dalam pemulihan.

Kata kunci: relaxation therapy; recovery Tidal Model; resiko perilaku kekerasan

\section{PENDAHULUAN}

Perilaku bizar, bicara kacau, afek tidak tepat, waham, halusinasi, dan gangguan pikiran merupakan tanda dan gejala positif dari skizofrenia. Pada gejala negatif merupakan gejala dengan perilaku normal yang berkurang, gejala gejala ini harus timbul setidaknya dalam jangka waktu 1 bulan dan hadir berturut - turut dalam jangka waktu 6 bulan. Perilaku ini akan disusun dalam kategori Kognitif, Persepsi, Emosi, Perilaku dan Sosialisasi. Gejala skizofrenia yang berlangsung dalam jangka waktu 1 bulan dan kurang dari 6 bulan disebut schizophreniform (Ruiz \& Sadock, 2017).

Skizofrenia dapat dialami oleh lebih dari 21 juta orang di seluruh dunia dan lebih sering terjadi pada laki-laki (12 juta) dibandingkan perempuan (9 juta) (WHO,2014). Prevalensi gangguan jiwa berat menurut Riskesdas (2018) terdapat $0,18 \%$ per mil kejadian di Indonesia dan $17,7 \%$ mengalami pemasungan dan terjadi pada daerah pedesaan. Prevalensi gangguan jiwa berat pada Provinsi Jawa Barat adalah 0,14\%. Dilihat dari prevalensi kejadian di atas, penulis berasumsi bahwa gangguan jiwa merupakan gangguan yang butuh diperhatikan oleh pemerintah dan juga keluarga.

Masalah emosi merupakan salah satu tanda gejala yang dimiliki oleh perilaku kekerasan. Interaksi aktivitas saraf antara hipotalamus, struktur limbik (amygdala dan hyppocampus), dan pusat - pusat korteks yang lebih tinggi yang merupakan psikofisiologis terjadinya emosi pada sistem manusia. Ketidakberfungsian dengan baiknya amygdala tersebut yang dapat mengakibatkan terjadinya perilaku kekerasan (Stuart, 2016). Selain itu peningkatan aktivitas dopamin juga berkaitan dengan peningkatan perilaku kekerasan. Semakin tingginya kejadian skizofrenia kemungkinan akan meningkatkan kejadian perilaku kekerasan.

Pada gangguan jiwa kronis diperkirakan mengalami kekambuhan 50\% pada tahun pertama, dan $70 \%$ pada tahun kedua. Kekambuhan biasanya terjadi karena adanya kejadian-kejadian buruk 
sebelum mereka kambuh dan juga dapat disebabkan oleh beberapa faktor, diantaranya faktor internal dan faktor eksternal (Suprayitno, 2010 dalam Sari, et al., 2018). Pemulihan yang baik merupakan hal yang penting dalam menghindari kekambuhan. Pemulihan merupakan proses dimana seseorang mampu untuk hidup, bekerja, belajar dan berpartisipasi secara penuh di dalam komunitasnya. Pada pemulihan memiliki aspek terpenting yang didefinisikan oleh setiap individu dengan pertolongan dari pemberi layanan kesehatan jiwa dan orang yang terpenting dalam hidup individu tersebut (Stuart, 2013).

Recovery (pemulihan) pasien gangguan jiwa ditujukan pada perbaikan gejala, menurunkan angka perawatan di rumah sakit, risiko kekambuhan yang kecil, dapat bersaing dalam pekerjaan, memperbaiki kualitas hidup dan memperbaikit keterlibatan di masyarakat. Pasien memerlukan pemulihan atau recovery yang dibutuhkan dalam mencegah kekambuhan. Tujuan dari recovery (pemulihan) pasien gangguan jiwa adalah bebas tanda dan gejala dengan cara memperbaiki strategi pengurangan tanda dan gejala (Prat, et al. 2014). Pada pemulihan merupakan hal yang penting untuk menciptakan kerja sama yang baik antara pasien dengan perawat. Komunikasi yang baik akan membuat perawat mengidentifikasi kebutuhan pasien dan memperdayakan kemampuan pasien serta membuat komitmen dan mendukung pasien untuk menceritakan pengalamannya yang akan bersamasama menentukan pelaksanan keperawatan untuk mengurangi tanda dan gejala dan menghasilkan pemulihan. Dalam hal ini perawat akan memberikan dukungan penuh untuk mengoptimalkan kemandirian pasien dalam berlatih kegiatan.

Komitmen tersebut merupakan penerapan recovery dalam Model Tidal yang membantu pasien membuat suatu perubahan dalam hidup mereka, tidak hanya sekedar mengatasi atau mengontrol gejala (Barker dalam Townsend, 2014). Kemampuan perawat meliputi membantu pasien mengungkapkan dalam bahasa mereka sendiri pemahaman mereka tentang pengalaman pribadi melalui penggunaan cerita, penangkal, dan metafora (Barker dalam Townsend, 2014). Hubungan saling percaya pasien dan perawat merupakan awal belajar dan berlatih keterampilan baru, selain memberikan umpan balik yang tidak menghakimi 
tentang kemajuan terapi, dan menjamin pemberian dukungan selama proses terapi. Penyediaan sumberdaya, pemberdayaan sumber daya yang telah ada membantu pasien mengambil keputusan melakukan recovery, membangun kekuatan pasien sehingga mendapatkan kembali kontrol atas hidupnya (Townsend, 2014).

Mendapatkan kembali kontrol pada perilaku kekerasan bukan lah hal yang mudah, dengan kerja sama yang baik antara pasien dengan perawat akan membuat proses pemulihan dengan baik. Penulis berasumsi bahwa Relaxation Therapy dimana tarik napas dalam merupakan tidakan yang dapat mengurangi tanda dan gejala resiko perilaku kekerasan dapat didiskusikan bersama dengan pasien untuk dapat menerapkannya dengan baik. Teknik relaksasi nafas dalam dapat dilakukan secara sederhana yang terdiri dari napas abdomen dengan frekuensi lambat dan berirama. Pada penelitian Sutinah, et al (2019) mengatakan ada perbedaan mengontrol marah sebelum dan sesudah dilakukan relaksasi nafas dalam terhadap mengontrol marah pada skizofrenia. Tarik napas dalam yang merupakan terapi generalis yang banyak sudah digunakan. Dengan dilakukannya tarik napas dalam akan mendukung terjadinya pemulihan, dimana akan didapatkan tanda dan gejala perilaku kekerasan berkurang jika dilakukan secara terjadwal. Sejalan dengan temuan pada penelitian Prasetya, 2018 bahwa pemberian jadual kegiatan sehari-hari secara signifikan bermanfaat dalam menurunkan kemampuan mengontrol resiko perilaku kekerasan. Kunci untuk membuat pernapasan dalam menjadi teknik relaksasi yang efektif adalah dengan sering berlatih dan menerapkannya dalam berbagai situasi.

Dengan bersama-sama pasien dan perawat menentukan Relaxation Therapy sebagai terapi yang akan dilakukan, dan mendapatkan bantuan atau dukungan dari perawat maka akan berkurangnya tanda dan gejala perilaku kekerasan dan tercapainya recovery. Menurut Keliat, et al (2019) tarik napas dalam merupakan terapi relaksasi yang merupakan tindakan keperawatan yang diajarkan kepada pasien dengan resiko perilaku kekerasan. Seringkali ketika emosi, klien mulai mengambil napas pendek dan akhirnya dapat membuat mereka merasa ringan kepala, pusing dan tidak terkendali. Napas dalam juga dapat mengatasi gejala fisik ini dan juga memungkinkan individu untuk 
mengambil "waktu" dari situasi tegang dan fokus pada sesuatu selain apa yang memicu kemarahan pada awalnya. Proses ini cukup mudah digunakan dan seringkali tidak terlihat oleh orang lain. Berbagai bentuk pelatihan relaksasi telah digunakan untuk mengurangi dampak buruk kemarahan. Pernapasan dalam telah terbukti secara efektif mengurangi tingkat kemarahan pada individu yang mengalami kesulitan bersantai dalam situasi kemarahan. Napas dalam dapat didefinisikan sebagai pernapasan diafragma lambat yang menyeimbangkan kadar oksigen dan karbon dioksida dalam tubuh (Ranjitham, 2016). Laporan kasus ini bertujuan untuk menyajikan tindakan Relaxation Therapy dimana dapat membuat perubahan dalam tanda-tanda dan gejala untuk mendapatkan pemulihan (recovery), dimana masih sedikit pembahasan mengenai terapi ini untuk mendapatkan pemulihan. Recovery pasien resiko perilaku kekerasan dapat dilakukan oleh perawat jiwa ini dilakukan dengan menggunakan pendekatan Tidal Model dimana pada kasus ini perawat mencoba untuk memenuhi hubungan saling percaya antara perawat dan pasien dan juga meningkatkan kesadaran diri pasien untuk tetap dapat melaksanakan relaxation therapy.

\section{METODE}

Penulisan manuskrip ini berdasarkan pengalaman praktik klinik keperawatan jiwa yang dilakukan oleh penulis. Penulis mendapatkan pasien kelolaan melalui bimbingan pada saat melaksakan praktik klinik. Pemberian asuhan keperawatan dilakukan secara langsung pada pasien. Pada saat pemberian asuhan keperawatan ini penulis memperhatikan aspek etik yang sudah diterapkan sesuai dengan prinsip etik keperawatan. Desain penulisan yang digunakan adalah studi kasus dan literature review. Sumber literature review yang didapatkan dari pencarian google schoolar, science direct, dan Wiley. Penulis mendapatkan 34 literatur, dan literatur yang digunakan sejumlah 10 jurnal. Subjek dalam studi kasus ini adalah penderita skizofrenia dengan masalah utama resiko perilaku kekerasan yang sedang dirawat di Rumah Sakit pada saat praktik klinik Keperawatan Jiwa. Asuhan keperawatan dilakukan berdasarkan tahapan proses keperawatan. Tahapan ini dimulai dari pengkajian, analisis data, penegakkan diagnosis, perencanaan intervensi keperawatan, implementasi, serta evaluasi. Identifikasi masalah yang 
diterapkan pada pasien dengan menggunakan scanning pengkajian jiwa lanjut secara langsung. Tindakan keperawatan yang dilakukan adalah relaxation therapy. Hal ini juga diterapkan pada hasil studi kasus Rizki \& Wardani, (2020) yang juga menerapkan asuhan keperawatan berdasarkan tahapan proses keperawatan, dari pengkajian, analisis data, $\mathrm{n}$ diagnosis, perencanaan intervensi keperawatan, implementasi, serta evaluasi.

\section{Ilustrasi Kasus :}

Pada Tn. A (23) adalah pasien dengan diagnosa keperawatan resiko perilaku kekerasan yang dirawat. Pasien melanjutkan pendidikan sampai mahasiswa, pasien mengatakan masih belum dapat menyelesaikan pendidikan dengan baik. Pasien mengatakan dirinya sempat bekerja tapi tidak lama setelah itu pasien kambuh dan harus dibawa ke RS. Menurut Tn. A dirinya sudah pernah dirawat di RS ini sebelumnya. Pada saat pengkajian Tn. A mengatakan riwayat dirawat sebelumnya adalah pada tahun 2019 dan lama rawat selama 1 bulan, menurut Tn. A ini terjadi karena jarang minum obat yang disebabkan oleh tidak ada satupun yang mengingatkan untuk minum obat di di rumah. Selain itu kemampuan yang dimiliki untuk mengatasi marah yang dimiliki Tn. A sangat minimal. Tetapi pasien masih dapat menyebutkan beberapa tindakan keperawatan yang sebelumnya sudah diajarkan. Pasien juga sudah mulai mengenali faktor yang menyebabkan marah pada dirinya. Pada saat pengkajian, pasien mengatakan jarang melakukan tindakan keperawatan yang sudah diajarkan di rumah atau hampir tidak pernah.

Hal ini didukung karena pasien merasakan tidak adanya dukungan yang pasien dapat untuk membantu pasien dalam menerapkan tindakan keperawatan tersebut. Dalam keluarga Tn. A, ia merupakan anak laki-laki satusatunya atau yang sering disebut dengan anak tunggal. Pasien tinggal bersama dengan ayah. Komunikasi di dalam keluarganya merupakan komunikasi 1 arah, dimana hubungan pasien dengan ayah tidak terlalu dekat. Didapatkan hubungan dengan lingkungan sekitarpun kurang baik, dimana stigma mengenai gangguan jiwa masih dirasakan pasien karena sering dikatakan gila. Dari cerita pasien tersebut pada saat pengkajian membuat pasien akhirnya kambuh dan tidak bisa menjalankan pemulihan dengan baik. Pada saat pengkajian pada 
sumber koping bagian positive belief pasien mengatakan bahwa pasien mempunyai harapan untuk sembuh, menjadi lebih dewasa dan berubah. Pasien juga menyatakan harapannya kepada tenaga kesehatan untuk dapat membantu dirinya menjadi lebih baik dan sembuh. Slade (2010) juga menjelaskan bahwa salah satu faktor yang penting untuk pemulihan adalah harapan.

Berdasarkan kasus yang didapat perawat memberi intervensi Tarik Napas Dalam pada hari pertama, dimana pasien setuju menerapkan tarik napas dalam untuk intervensi pertama mengurangi marah. Kemampuan relaxation therapy ini sangat dibutuhkan oleh pasien. Teknik yang perawat ajarkan kepada pasien yaitu edukasi pasien di posisi yang rileks dan nyaman, lalu tarik nafas dalam dengan lewat hidung dengan hitungan 1,2,3 lalu hembuskan perlahan lahan dan dilakukan 3 kali atau senyamannya mungkin. Irama yang konstan dipertahankan dengan menghitung dalam hati dan lambat bersama setiap inhalasi dengan cara hirup, dua, tiga dan ekshalasi dengan hembuskan, dua, tiga. Relaxation therapy ini memerlukan waktu 5 sampai 10 menit. Pasien mengikutinya dengan baik dan dapat dilakukan juga dengan mandiri, terlihat pada saat evaluasi. Hal ini sesuai dengan terapi generalis ners yang diperuntukkan untuk gangguan resiko perilaku kekerasan.

Menurut Keliat, et al (2019) tarik napas dalam merupakan terapi relaksasi yang merupakan tindakan keperawatan yang diajarkan kepada pasien dengan resiko perilaku kekerasan. Hal ini juga disampaikan oleh penelitian (Busch et al., 2012) mengatakan berkenaan dengan keadaan suasana hati, ditemukan pengurangan yang signifikan dari ketegangan, kemarahan, dan perasaan depresi setelah Deep and Slow Breathing, menunjukkan penurunan tingkat stres yang lebih umum. Pasien mengatakan hal ini dapat menurunkan rasa marahnya dalam hati. Hasil dari latihan ini juga dapat membuat pasien menjadi lebih tenang, dibuktikan dengan evaluasi pasien oleh perawat dimana pasien mengatakan bahwa dirinya lebih tenang, ini dapat membantu pasien untuk mengontol marah. Hal ini juga dijelaskan oleh Suhron (2015) membahas Dengan demikian efektifitas terapi relaksasi nafas dalam menurunkan perilaku kekerasan pada pasien perilaku kekerasan cukup baik, efektif, efisien dan mudah dilakukan sendiri. Dengan 
melakukan latihan ini tubuh akan berespon untuk menvasodilatasi pembuluh darah, meningkatkan ventilasi alveoli dan memberikan perasaan yang tenang dan nyaman.

Perawat melakukan evaluasi pada hari kedua dan pasien dapat melakukannya dengan baik dan benar, selain itu perawat juga memberikan jadwal untuk dapat melakukan tindakan tarik napas dalam secara rutin dan terjadwal. Tindakan tersebut dimaksudkan kepada Relaxation Therapy. Hal ini sesuai dengan terapi generalis ners yang diperuntukkan untuk gangguan resiko perilaku kekerasan. Pada saat evaluasi pasien mengatakan kembali harapannya yaitu harapan untuk sembuh, menjadi lebih dewasa dan berubah. Pasien juga mengatakan akan melakukannya lebih terjadwal dan sering sehingga dapat mencapai harapan yang ada dalam dirinya. Evaluasi dalam melakukan relaxation therapy sebelum dan sesudah dalam waktu asuhan keperawatan 3 hari. Data yang didapat merupakan data pada saat pengkajian dan evaluasi pada keesokan harinya. Pada saat pengkajian beberapa tanda dan gejala terlihat pada pasien, pasien juga menyebutkan beberapa tanda dan gejala yang biasanya pasien rasakan pada saat marah. Pasien mengatakan hal ini pernah diajarkan oleh perawat sebelumnya tetapi pasien tidak pernah melakukannya secara rutin. Evaluasi dilakukan pada hari selanjutnya dimana perawat melakukan pengkajian terhadap intervensi Relaxation Therapy.

Pada saat evaluasi perawat meminta pasien kembali untuk melakukan kembali terapi tersebut, terlihat pasien dapat melakukannya secara mandiri. Perawat juga melakukan observasi dan wawancara kembali terhadap tanda dan gejala yang ada pada pasien. Pasien mengatakan bahwa adanya perubahan yang terjadi pada saat melakukan Relaxation Therapy. Pasien mengatakan intervensi tersebut membuat pasien lebih tenang, tidak berpikir negatif dan dapat mengontrol rasa ingin marah pasien. Lalu perawat menggunakan intrumen tanda dan gejala terlihat beberapa tanda dan gejala sudah berkurang, ini didapat dari hasil observasi dan wawancara langsung kepada pasien. Perubahan tanda dan gejala belum secara signifikan terlihat, tetapi pasien mengatakan akan melakukannya secara rutin, karena harapan pasien akan sembuh dan menjadi berubah lebih dewasa. Selain itu diperlukan komitmen untuk pasien dapat melakuaknnya dalam kegiatan seharihari. Menurut asumsi penulis manfaat ini 
juga bisa menjadikan pasien dapat dalam secara sistematis dan terjadwal melakukan tarik napas

Tabel 1. Evaluasi Tanda dan Gejala yang ditemukan pada saat pengkajian dan evaluasi

\begin{tabular}{|c|c|c|}
\hline Tanda dan gejala & Pre & Post \\
\hline \multicolumn{3}{|l|}{ Kognitif } \\
\hline \multicolumn{3}{|l|}{ 1.1 Subjektif } \\
\hline Mengungkapkan ketidakmampuan mengontrol PK & $\checkmark$ & - \\
\hline Merasa berpikir negatif dalam menghadapi stressor & $\checkmark$ & - \\
\hline \multicolumn{3}{|l|}{ Mengungkapkan keinginan untuk memukul orang lain } \\
\hline \multicolumn{3}{|l|}{ Mengungkapkan ketidakmampuan dalam berkomunikasi } \\
\hline \multicolumn{3}{|l|}{1.2 Objektif } \\
\hline \multicolumn{3}{|l|}{ Mendominasi pembicaraan } \\
\hline \multicolumn{3}{|l|}{ Flight of idea } \\
\hline \multicolumn{3}{|l|}{ Perubahan isi piker } \\
\hline Menyalahkan orang lain & $\checkmark$ & $\checkmark$ \\
\hline \multicolumn{3}{|l|}{ Kurang konsentrasi } \\
\hline Mudah putus asa & $\checkmark$ & $\checkmark$ \\
\hline \multicolumn{3}{|l|}{ Kepribadian tertutup } \\
\hline \multicolumn{3}{|l|}{ Agresif } \\
\hline \multicolumn{3}{|l|}{ Afektif } \\
\hline \multicolumn{3}{|l|}{ 2.1 Subjektif } \\
\hline \multicolumn{3}{|l|}{ Afek labil } \\
\hline \multicolumn{3}{|l|}{ Mengungkapkan perasaan curiga } \\
\hline \multicolumn{3}{|l|}{ Merasa mudah tersinggung } \\
\hline \multicolumn{3}{|l|}{ Merasa tidak nyaman } \\
\hline Merasa jengkel & $\checkmark$ & - \\
\hline \multicolumn{3}{|l|}{ Mengungkapkan keinginan untuk memukul orang } \\
\hline \multicolumn{3}{|l|}{ 2.2 Objektif } \\
\hline Marah & $\checkmark$ & - \\
\hline \multicolumn{3}{|l|}{ Frustasi } \\
\hline \multicolumn{3}{|l|}{ Pemurung } \\
\hline Menunjukkan ketidakpedulian dengan lingkungan/acuh & $\checkmark$ & $\checkmark$ \\
\hline \multicolumn{3}{|l|}{ Sering meremehkan sesuatu } \\
\hline Kurang percaya diri & $\checkmark$ & $\checkmark$ \\
\hline
\end{tabular}

\begin{tabular}{lll}
\hline Fisiologi & \\
\hline 3.1 Subjektif & \\
\hline Mengatakan pusing & $\checkmark$ & - \\
\hline Merasa berdebar-debar
\end{tabular}

\section{Mengungkapkan keluhan mual, tidak enak di perut}

\begin{tabular}{l}
\hline 3.2 Objektif \\
\hline Muka merah \\
\hline Pandangan tajam \\
\hline Rahang mengatup dengan kuat \\
\hline Tangan mengepal \\
\hline Wajah tegang dan kewaspadaan meningkat \\
\hline Frekuensi BAB dan BAK cenderung meningkat \\
\hline
\end{tabular}




\begin{tabular}{lll}
\hline \multicolumn{1}{c}{ Tanda dan gejala } & Pre & Post \\
\hline 4.1 Subjektif & $\checkmark$ & $\checkmark$ \\
\hline Mengatakan selalu curiga & & \\
\hline Mengungkapkan keinginan untuk melukai diri sendiri lorang lain & \\
\hline 4.2 Objektif & \\
\hline Mondar-mandir & $\checkmark$ \\
\hline Memukul benda/orang & \\
\hline Merusak barang & \\
\hline Nada suara tinggi/keras & \\
\hline Agresif & \\
\hline Suka membentak orang lain & \\
\hline Bersikap sinis terhadap orang lain & \\
\hline \begin{tabular}{l} 
Sosial \\
\hline S.1 Subjektif
\end{tabular} & \\
\hline Sering mengungkapkan keinginannya dengan nada mengancam & $\checkmark$ \\
\hline Secara verbal sering mengejek, mengolok-olok & \\
\hline Menarik diri dalam pergaulan lingkungan sekitar & \\
\hline Mengasingkan diri & \\
\hline Penolakan & \\
\hline
\end{tabular}

\section{HASIL DAN PEMBAHASAN}

Pada hasil dan pembahasan di bawah ini akan dibahas menjadi 2 topik utama yaitu therapeutic relationship dan self awareness. Pada teori recovery Tidal Model ditemukan beberapa komitmen pada proses pemulihan, yaitu menghargai suara dan cerita pasien, mengembangkan rasa ingin tahu dari perawat yang tulus dan menunjukkan minat untuk mendengarkan mereka sehingga perawat dan pasien bekerja sama untuk membangun apresiasi tentang apa yang perlu dilakukan hal ini dapat dikategorikan sebagai Therapeutic relationship (nurse and patient). Hubungan ini dapat berjalan dengan baik dengan pengertian bahwa pasien tahu apa yang terbaik untuknya dan pasien memiliki semua sumber daya yang mereka butuhkan untuk memulai perjalanan pemulihan. Hal ini dapat dikategorikan sebagai Self Awareness (Alice, P. 2020). Hal ini dikaitkan bahwa pasien merasa memiliki kesadaran untuk mengelola perawatan diri sendiri. Salah satunya yaitu melaksanakan terapi yang sudah disepakati oleh pasien dan perawat yaitu relaxation therapy. Sejalan dengan penelitian Garcia \& Palompon, (2012) mengatakan pasien merencanakan kesembuhannya sendiri dan dapat bertindak sendiri. Perawat ada hanya untuk memfasilitasi dan memastikan bahwa pasien melakukan hal yang benar. Barker, (2001) mengatakan Model Tidal 
mengasumsikan bahwa perawat perlu dekat dengan pasien yang ada dalam perawatan mereka, sehingga mereka dapat mengeksplorasi (bersama-sama) pengalaman kesehatan dan penyakit.

\section{Therapeutic relationship (nurse and patient)}

Pada pemulihan ini diharapkan ada hal yang datang dari dalam diri pasien yang sepenuhnya akan membantu pasien untuk pulih dan dapat mandiri. Barker \& Buchanan-Barker, 2007 dalam Alligood (2014) mengungkapkan dengan melalui Tidal Model, dalam penilaian holistik perawat mengeksplorasi masalah atau kebutuhan pasien, dapat membantu menyelesaikan masalah atau memenuhi kebutuhan untuk membawa tentang perubahan. Tidal model menekankan pada kerja kolaboratif interdisipliner, dan mengembangkan hubungan terapeutik (Barker, 2000 dalam Alligood, 2014). Basis kekuatan Tidal Model adalah menekankan mencari dan mengungkapkan solusi dan mengidentifikasi sumber daya.

Perawat berusaha mendengarkan dan merasakan penderitaan pasien dan juga memberikan harapan untuk resolusi masalahnya. Perawat juga mendorong pasien untuk bercerita dengan kata-kata pasien sendiri dengan cara khasnya, ini akan membantu pasien menyampaikan dengan sederhana dan dengan arti yang kuat bagi pasien. Hal ini didukung oleh penelitian Feng (2017) didapatkan pasien yang mengalami ketergantungan dan menjalani pemulihan jangka panjang memiliki harapan untuk hidup kembali. Pada kasus ini perawat mendengarkan pasien bercerita tentang riwayat dirawat sebelumnya adalah pada tahun 2019 dan lama rawat selama 1 bulan, dimana ini terjadi karena jarang minum obat yang disebabkan oleh tidak ada satupun yang mengingatkan untuk minum obat. Pada kasus ini didapatkan cerita pasien melalui pengkajian pada pendekatan Stuart, hubungan saling percaya sudah didapat dengan baik sehingga pasien dapat menceritakan pengalamannya. Hasil penelitian Lynch (2012) mengatakan bahwa hubungan yang dibangun dengan pasien merupakan indikasi hasil yang sukses.

Lebih dari sekedar pemahaman itu menunjukkan bahwa dari hasil pengalaman pasien, perawat merasakan juga apa yang dikatakan. Hasil dari rasa empati akan membantu meningkatkan hubungan baik dengan komunikasi terapetik yang digunakan perawat dalam berhubungan dengan pasien. Terjalinnya 
hubungan yang saling percaya antara perawat dan pasien jiwa ini menghasilkan hubungan terapeutik yang komunikatif. Pesan-pesan persuasif yang ditingkatkan dan dikembangkan pada setiap fase komunikasi terapeutik mempengaruhi pemahaman, penerimaan dan perubahan perilaku pada pasien baik secara kognitif, afektif dan perilaku. (Pasaribu, R. 2014). Penelitian Carr (2011) menemukan bahwa psikoterapi yang tidak efektif ketika seorang terapis hadir dan tidak mampu menunjukkan kepedulian yang tulus dan empati. Pada kasus pasien menceritakan bahwa alasan pasien dibawa ke rumah sakit karena kambuhnya perilaku marah pasien. Dimana kemampuan yang dimiliki untuk mengatasi marah yang dimiliki pasien sangat minimal. Tetapi pasien masih dapat menyebutkan beberapa tindakan keperawatan yang sebelumnya sudah diajarkan. Dengan hubungan dan pemahaman perawat yang baik, perawat dapat belajar dari pengalaman yang diceritakan oleh pasien dan perawat juga dapat mengeksplorasi mengenai kebutuhan pasien

\section{Self awareness}

Mendengarkan dan memahami cerita pasien dan mengeksplorasi kebutuhan pasien lalu dilanjutkan dengan melangkah bersama mencari jalan keluar. Perawat dan pasien bekerja sama untuk membangun apresiasi terhadap apa yang perlu dilakukan dalam setiap langkah penting, mengungkapkan kekuatan perubahan yang mungkin dapat dilakukan dan mengarah ke kehidupan saat ini yaitu tujuan pemulihan (Jalil, 2014). Pada kasus diatas tindakan yang sudah disepakati bersama yaitu tindakan relaxation therapy yaitu tarik napas dalam. Pasien setuju menerapkan tarik napas dalam untuk intervensi pertama mengurangi marah. Pasien mengatakan hal ini dapat menurunkan rasa marahnya dalam hati. Setelah pasien mau diajak untuk melakukan perilaku tersebut dengan pola komunikasi yang baik seperti dijelaskan sebelumnya, menjadikan pasien mau untuk melakukan terapi (Pasaribu, R. 2014).

Tarik napas dalam merupakan tindakan generalis dari resiko perilaku kekerasan. Hal ini sesuai dengan diagnosa yang didapatkan pada kasus. Diyakini bahwa tarik napas dalam dapat mengurangi rasa marah pada reisko perilaku kekerasan yang berarti tanda dan gejala akan berkurang dan tercapainya pemulihan. Berbagai bentuk pelatihan relaksasi telah digunakan untuk mengurangi dampak buruk kemarahan. Pernapasan dalam 
telah terbukti secara efektif mengurangi tingkat kemarahan pada individu yang mengalami kesulitan bersantai dalam situasi kemarahan. Napas dalam dapat didefinisikan sebagai pernapasan diafragma lambat yang menyeimbangkan kadar oksigen dan karbon dioksida dalam tubuh (Ranjitham, 2016). Pada kasus didapatkan pasien mengatakan hal ini dapat menurunkan rasa marahnya dalam hati. Kinandika (2014) mendapatkan setelah diajarkan teknik relaksasi nafas dalam, respon pasien tampak tenang dan rileks, hal itu menunjukkan bahwa ada pengaruh teknik relaksasi nafas dalam dengan perilaku kekerasan yang dialami pasien, teknik relaksasi tidak hanya menyebabkan efek yang menenangkan fisik tetapi juga menenangkan pikiran.

Melakukan relaksasi napas dalam dapat membantu pasien mendapatkan kembali kontrol emosinya dan menurunkan ketegangan juga menurunkan perilaku agitasinya (Stuart, 2013). Pemulihan dapat dimulai dari tahap awal kesadaran pasien bahwa mereka akan menunjukkan perubahan ke arah yang positif yang mungkin terjadi. Kesadaran diri pasien, bagaimana pasien dapat memberikan dukungan pada dirinya sendiri tepat bagi dirinya dalam menjalani pemulihan.
Kesadaran diri (Self-awareness) sangat penting dalam menjalani recovery sehingga pemberian terapi dapat langsung dirasakan manfaatnya dan mereka akan menunjukkan perubahan ke arah yang positif yang mungkin terjadi.

Meningkatkan kesadaran diri tentang pentingnya latihan, membantu pasien mengeksplor dirinya sendiri dan perawat mendukung pasien dalam menjalankan program pemulihan. Menurut asumsi penulis ini memberikan dukungan harapan dapat meningkatkan kesadaran pada diri pasien untuk pulih. Memiliki harapan pada pemulihan merupakan hal yang harus terjadi. Individu yang memiliki harapan akan memotivasi pemulihan untuk masa depan yang lebih baik. Memiliki harapan memainkan peran penting dalam pemulihan individu (Stuart, 2010). Karena kesadaran diri ini pasien dapat melakukan kembali terapi tersebut, terlihat pasien dapat melakukannya secara mandiri. Perawat dapat memberikan waktu kepada pasien untuk memberikan dukungan harapan yang akan memperluas kesadaran pasien yang juga akan mendukung pasien dalam menerapkan terapi dengan baik. Pada kasus ini didapatkan pasien mempunyai harapan untuk sembuh, menjadi lebih dewasa dan berubah. Pasien juga 
menyatakan harapannya kepada tenaga kesehatan untuk dapat membantu dirinya menjadi lebih baik dan sembuh.

Mendampingi pasien dan mendukung pasien secara penuh dapat mengembangkan kesadaran tentang bagaimana perubahan terjadi dan untuk mendukung orang tersebut dalam membuat keputusan terkait pemulihan. Menurut asumsi penulis mengembangkan kesadaran dapat juga dengan meningkatkan motivasi untuk melaksanakan tindakan dengan baik. Motivasi ini juga dapat membuat pasien melakukan tindakan secara mandiri yang akan menurunkan tanda dan gejalan perilaku kekerasan dan tercapainya pemulihan. Hasil penelitian Lynch (2012) menemukan bahwa motivasi pasien merupakan kunci untuk meningkatkan hasil yang sukses dari sebuah psikoterapi. Dalam hal ini perawat juga akan selalu membantu orang tersebut memahami mengenai terapi yang sudah ditentukan. Pemahaman ini juga akan meningkatkan kesadaran pasien dalam menjalakan terapi.

Pada kasus ditemukan kesadaran pasien mengatakan akan melakukannya lebih terjadwal dan sering sehingga dapat mencapai harapan yang ada dalam dirinya. Pasien mengatakan bahwa ada nya perubahan yang terjadi pada saat melakukan Relaxation Therapy. Pasien mengatakan terapi tersebut membuat pasien lebih tenang, tidak berpikir negatif dan dapat mengontrol rasa ingin marah pasien. Dijelaskan bahwa pasien sudah memiliki pondasi dari pemulihan yang berfokus pada diri sendiri, kesadaran dapat meningkatkan ketertarikan pasien untuk pulih, dimana mereka percaya bahwa mereka akan melakukan semua yang mereka harapkan dengan baik. Pada penelitian Prasetya, 2018 bahwa pemberian jadual kegiatan sehari-hari secara signifikan bermanfaat dalam menurunkan kemampuan mengontrol resiko perilaku kekerasan. Kunci untuk membuat pernapasan dalam menjadi teknik relaksasi yang efektif adalah dengan sering berlatih dan menerapkannya dalam berbagai situasi. 
Skema 1. Relaxation therapy pada resiko perilaku kekerasan dengan aplikasi recovery therapy berdasarkan The Tidal Model

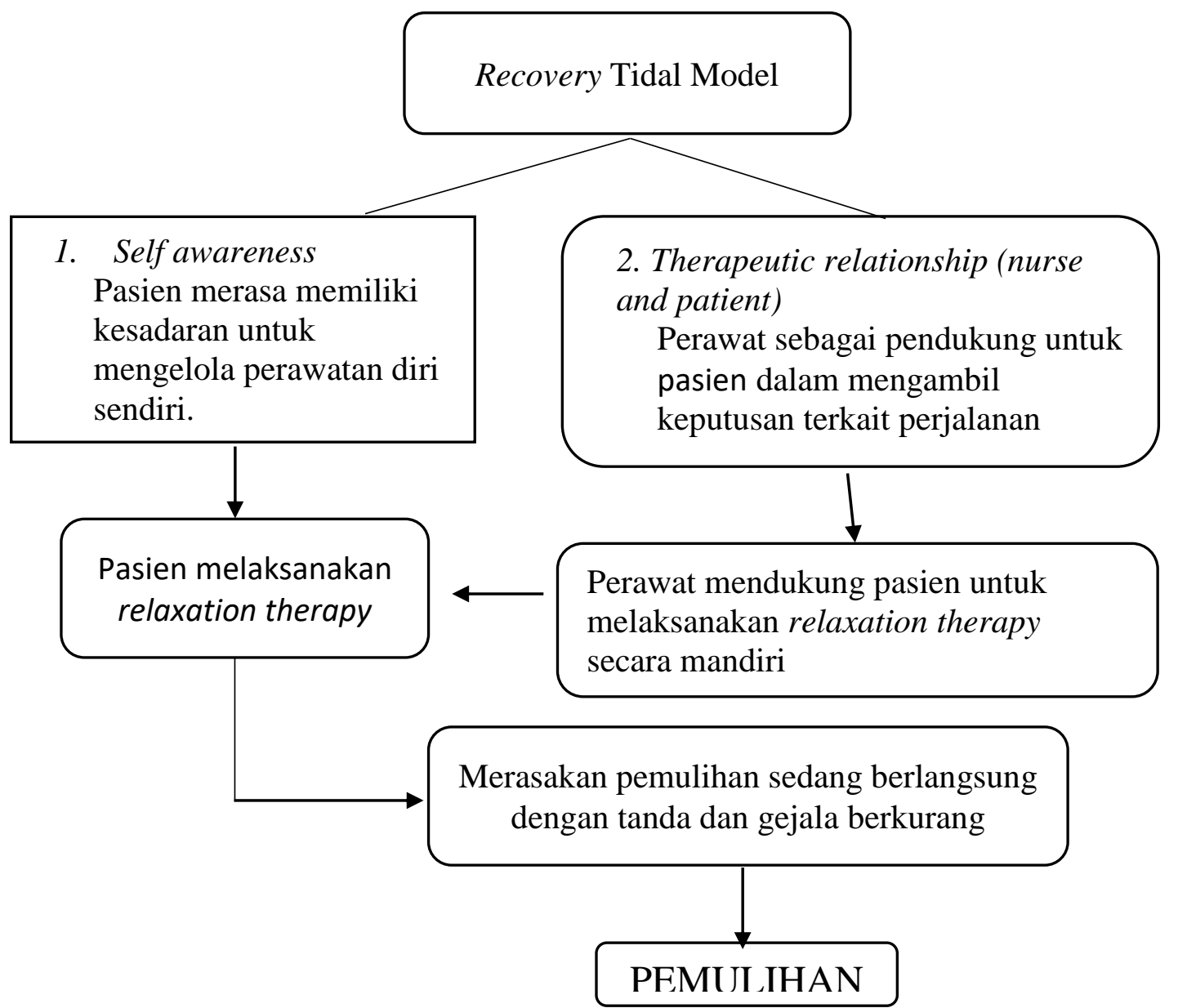

\section{SIMPULAN}

Komunikasi terapetik yang baik perawat dan pasien dapat membangun hubungan awal yang baik untuk menunjukkan bahwa perawat adalah orang yang peduli dan ingin menjadi teman berbicara bagi pasien. Dengan begitu perawat dapat menghargai cerita pengalaman pasien dan dapat belajar dari pengalaman tersebut yang dapat bersama-sama menentukan langkah awal terapi yang akan diberikan. Model Tidal ini tepat untuk menimbulkan rasa empati perawat dengan pola komunikasi yang baik menjadikan pasien mau melakukan terapi yang ditentukan bersama yaitu tindakan keperawatan tarik napas dalam yang dapat mengurangi tanda dan gejala resiko perilaku kekerasan, dan mengikuti aktivitas keseharian secara baik dan teratur karena dorongan dukungan perawat meningkatkan kesadaran diri pasien akan meningkatkan terjadinya 
pemulihan. Dengan demikian, terapi ini dapat diterapkan di bangsal perawatan dan menerapkan Tidal model yang mengakui beberapa cara memahami dunia termasuk memahami penyakit mental atau jiwa. Pemahaman perawat dan cerita pasien yang menggunakan bahasa sendiri dapat menurunkan ketegangan dan mempermudah pasien dan akan meningkatkan hubungan baik antara perawat dan pasien.

Laporan kasus ini merekomendasikan agar pasien dengan risiko perilaku kekerasan diberikan terapi tarik napas dalam ini dengan baik dan bertahap. Perawat dapat menolong pasien dengan membangun hubungan yang terapeutik dan memeberi dukungan motivasi untuk melakukan tarik napas dalam yang akan menimbulkan kesadaran diri pasien dengan tujuan utama pemulihan. Laporan kasus ini juga merekomendasikan agar perawat dapat mengidentifikasi kebutuhan pasien dan memperdayakan kemampuan pasien serta membuat komitmen untuk menceritakan pengalamannya menjadi sakit jiwa dan perjalanan recovery atau pemulihan yang telah dijalani serta makna hidup dan pengalaman spiritual yang dimiliki. Dimana potensi perawat dapat mendukung dan menolong pasien dalam mengembangkan keterampilan hidup mandiri, hubungan interpersonal, dan sumber koping yang pada akhirnya menolong untuk memenuhi kebutuhan khusus pasien kedepannnya.

\section{UCAPAN TERIMAKASIH}

Mengucapkan terima kasih kepada pasien untuk bisa menerapkan terapi ini dengan baik dan memperlihatkan evaluasi tindakan tersebut dengan hasil yang baik. Terimakasih kepada pembimbing dosen yang membimbing dalam penulisan manuskrip ini.

\section{DAFTAR RUJUKAN}

Alice, P. 2020. Barker's Tidal Model Of Mental Health Recovery. Diakses pada 27 Mei 2021. https://nursingtheory.org/theories-andmodels/barker-tidal-model-ofmental-health-recovery.php

Alligood, M.R. 2014. Nursing theorist and Work. Eight Edition. New York: Elsevier, Inc

Barker, P. 2001. Approach to Psychiatric and Mental Health Nursing. Perspectives in Psychiatric Care, 37(3), 79-87. 
Busch, V., Magerl, W., Kern, U., Haas, J., Hajak, G., \& Eichhammer, P. 2012. The Effect of Deep and Slow Breathing on Pain Perception, Autonomic Activity, and Mood Processing-An Experimental Study. Pain Medicine, 13(2), 215228.https://doi.org/10.1111/j. 1526 $-4637.2011 .01243 . \mathrm{x}$

Garcia, L., \& Palompon, D. 2012. Tidal Model in the Care of a Patient with bipolar 1 Disorder: A Journey to Recovery.

Rizki, D. D. G., \& Wardani, I. Y. 2020. Penurunan Perilaku Kekerasan Pasien Skizofrenia Melalui Praktik Klinik Online Di Masa Pandemi Covid-19. Jurnal Keperawatan Jiwa, 8(4), 369-382.

Carr, G.D. 2011. Psychotherapy Research: Implications For Practice. PsychiatricTimes, 28.8, 31.

Feng, K., Y. 2017. Being Young and Mentally Ill In Singapore: An Exploratory Study Of The Lived Experiences of Youths In Recovery From Mental Illness In Singapore. Honors Thesis.

Indonesia, K. P. 2014. Komunitas Peduli Skizofrenia Indonesia. (Peduliskizofrenia.Org: Http://www.Peduliskizofrenia.Org I) diakses April 2020.

Keliat, B.A, Hamid, A.Y., Putri, Y. S. E., Daulima, N. H. C., Wardani, I. Y., Susanti, H., Hargiana, G., \& Panjaitan, R. U. 2019. Asuhan Keperawatan Jiwa. Jakarta:EGC.
Keliat, B.A dan Akemat. 2012. Model Praktik Keperawatan Profesional Jiwa. Jakarta : EGC.

Kinandika, R. 2014. Pemberian Teknik Relaksasi Nafas Dalam Terhadap Penurunan Tingkat Emosi Pada Asuhan Keperawatan Tn. F Dengan Perilaku Kekerasan Di Ruang Puntadewa Rumah Sakit Jiwa Daerah Surakarta. Karya Tulis Ilmiah.

Leamy, M., Bird, V., Boutillier, C., Williams, J., \& Slade, M. 2011. Conceptual Framework For Personal Recovery In Mental Health: Systematic Review and Narrative Synthesis. The British Journal of Psychiatry.

Lynch, \& McCoy, M. 2012. Factors Influencing Successful Psychotherapy Outcomes. Disertasi. School of Social Work St. Catherine University \& University of St. Thomas St. Paul, Minnesota.Master of Social Work Clinical Research Papers. Paper 57.

http://sophia.stkate.edu/msw_pape $\underline{\mathrm{rs} / 57}$

Prasetya, S., A. 2018. Efektifitas Jadual Aktivitas Sehari-Hari Terhadap Kemampuan Mengontrol Perilaku Kekerasan. Jurnal Kesehatan Panca Bhakti Lampung, Volume Vi.

Pratt, C.W., Gill, K.J., Barret, N.M., Roberts, M.M. 2014. Psychiatric Rehabilitation. Third Edition. New York: Elsevier, Inc. 
Ranjitham, M. 2016. A Study To Assess The Effectiveness Of Deep Breathing Exercise On Reduction Of Anger Expression Among Adolescent Girls In Selected School At Vallioor. A Dissertation Submitted To The Tamil Nadu.

Riset Kesehatan Dasar (Riskesdas). 2018. Badan Penelitian dan Pengembangan Kesehatan Kementerian. Jakarta : Kementerian Kesehatan.

Rizki, D. D. G., \& Wardani, I. Y. 2020. Penurunan Perilaku Kekerasan Pasien Skizofrenia Melalui Praktik Klinik Online Di Masa Pandemi Covid-19. Jurnal Keperawatan Jiwa, 8(4), 369-382.

Sadock, B.J., Sadock, V.A., Ruiz, P. 2017. Kaplan And Sadock's Concise Textbook of Clinical Psychiaty. Lippincott Williams \& Wilkins, A Wolter Kluwer Company.

Sari, P., Y., Sapitri, N., V., \& Yaslina. 2018. Faktor-Faktor yang Berhubungan dengan Terjadinya Kekambuhan Pada Penderita Gangguan Jiwa Di Wilayah Kerja Puskesmas Sungai Dareh Kabupaten Dharmasraya. Jurnal Kesehatan Perintis (Perintis's Health Journal) Volume 5.
Slade, M. 2010. Mental Illness and WellBeing: The Central Importance of Positive Psychology and Recovery. Health Services Research.

Stuart, G.W. 2013. Priciples And Practice Of Psyciatric Nursing (10th Ed.). St Louis Missouri: Elsivier Mosby.

Stuart, G. W. 2016. Prinsip Dan Praktik Keperawatan Kesehatan Jiwa Stuart. Elsevier: Singapura. Editor : Budi Anna Keliat dan Jesika Pasaribu

Sutinah, Safitri, R., \& Saswati, N. 2019. Teknik Relaksasi Nafas Dalam Berpengaruh Terhadap Kemampuan Mengontrol Marah Klien Skizofrenia. Journal Of Healthcare Technology And Medicine Vol. 5.

Suhron, M. 2015. Efektivitas Terapi Relaksasi Nafas Dalam dan Terapi Tertawa Pada Pasien Perilaku Kekerasan. Jurnal Ilmiah Ilmu Keperawatan.

Townsend, M.C. 2014. Essentials of Psychiatric Mental Health Nursing Concepts of care in Evidence-Based Practice. Sixth Edition. Philadelphia: F.A. Davis Company. 